\title{
Painting the Void: The Instrumentalization of Cartography in Neo-Confucian Chosŏn and Renaissance France through Landscape Painting and Perspective $\left(15^{\text {th }}-16^{\text {th }}\right.$ centuries $)$
}

Jérémie Eyssette*

\section{Introduction}

Maps derive value from the balance between the information their cartographers supply or subtract. When involuntary, absence of data is attributed to negligence or ignorance. When intentional, it tends to connote deceit. Previous studies praised the plethora of entries which points to scientific precocity in Yi Hoe's (李曾, 1354-1409) P'altodo (八道圖, Map of the Eight Provinces, 1400) and Honil kangni yǒktae kukto chi to (混一 疆理歷代國都之圖, Map of Integrated Lands and Regions of Historical Countries and Capitals, 1402) or Kangnido, ${ }^{1}$ and in Oronce Fine's (1494-1555) Recens et integra orbis descriptio (1536) and Nova totius

Assistant Professor, Chosun University

1 Oh Sanghak, "Honil kangni yŏktae kukto chi to tamnon ŭi pip'anjŏk kŏmt'o," Han'gukkojidoyŏn'guhak'oe haksultaehoe (2012): 91-109; Nurlan Kenzheakhmet, "Central Asian Place Names in the Kangnido," Journal of Asian History 49, no. 12 (2015): 141-160; Nurlan Kenzheakhmet, "The Place Names of Euro-Africa in the Kangnido," The Silk Road 14 (2016): 106-125. Jerry Brotton, A History of the World in 12 Maps (New York: Viking, 2013), 114-145; Gari Ledyard, "Cartography in Korea," in The History of Cartography, ed. Catherine Delano Smith, Na 
Galliae descriptio $(1538)^{2}$-thereafter Fine's world map and France map. From a comparative perspective, one benefit from delving into the Kangnido's sources is to establish a connection with later Western cartography, and in particular with Oronce Fine (1494-1555) who also relied on Ptolemy and similar tools. Parallels can be extended to the political sphere. Both cartographers were closely linked to the powers that $\mathrm{be}^{3}$ at a time the burgeoning $\mathrm{Yi}$ and Valois dynasties were seeking to establish a new modus operandi with a continental hegemon -the Ming and Habsburg Empires.

An introduction to Yi Hoe and Fine's maps will show that they have already been credited with sharing common sources and reflecting these shifting circumstances. Missing from the literature, however, is a comprehensive analysis of cartographic instrumentalization through the prisms of landscape painting and perspective. At some overarching level, this research can be seen as a conversation between these painting traditions as insightfully analyzed by the art historians François Cheng and

than Sivin, Cordell Yee, et al. (Chicago: J.B. Harley et D. Woodward, 1994), 235345 .

2 Lt-colonel Langlois, "Étude sur deux cartes d'Oronce Fine de 1531 et 1536," Journal de la Société des Américanistes 14-15 (1922): 83-97 ; Lucien Gallois, "La grande carte de France d'Oronce Fine, "Annales de Géographie 44, no. 250 (1935): 337-348 ; Alexander Marr, The worlds of Oronce Fine, Mathematics, Instruments and Print in Renaissance France (Donington: Shaun Tyas, 2009).

3 In 1530, Oronce Fine was appointed as lecteur royal by Francis I at the first chair of mathematics at Collège Royal (today's Collège de France), a scientific and cultural institution founded by king Francis I that year. He held this position until his death in 1555. After passing the civil service examination in 1382, Yi Hoe served both in the Koryŏ and Chosŏn governments. Following King T'aejo's will to keep some military officers away from the defense ministry (兵曹正郎), Yi Hoe was exiled to Sunch'ŏn in 1394. The year he confectioned the Kangnido (1402), he was appointed as Legal Secretary (kömsang) and held official positions until his death in 1409. Kenneth Robinson, "Yi Hoe and His Korean Ancestors in T'aean Yi Genealogies,” Seoul Journal of Korean Studies 21, no. 2 (December 2008): 234-237. 


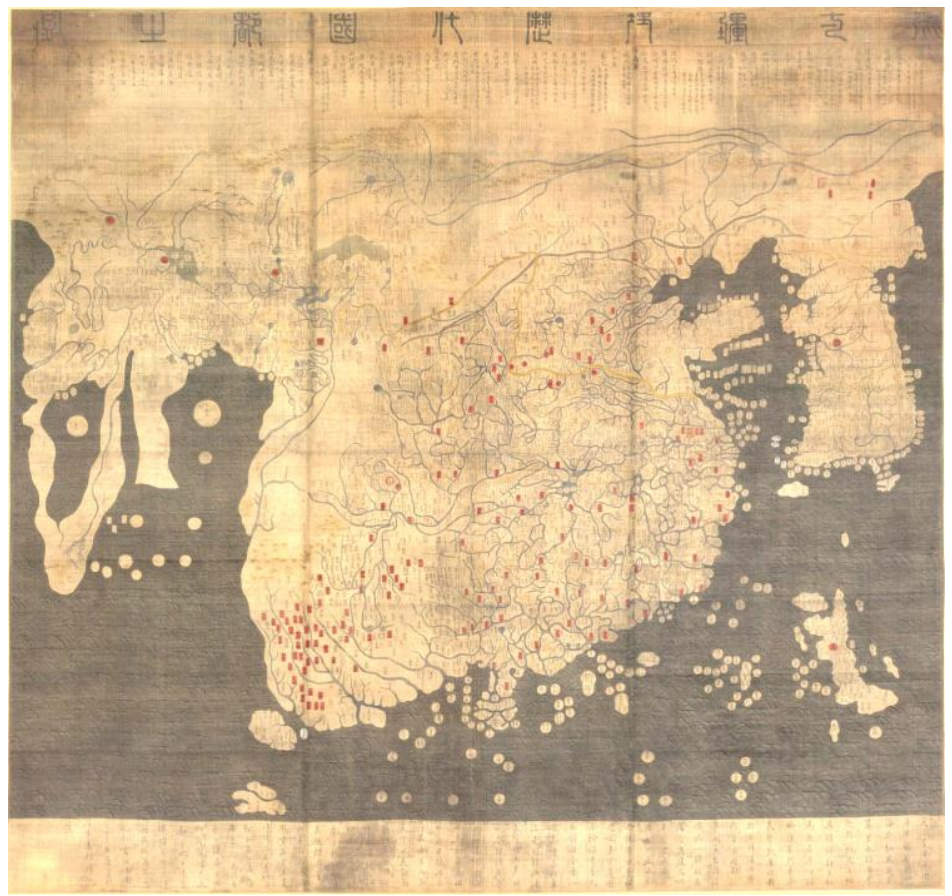

The Ryūkoku Kangnido (164 x 171.8 cm), 混一疆理歷代國都之圖, Honil kangni yǒktae kukto chi to, Map of Integrated Lands and Regions of Historical Countries and Capitals, 1479-1485.

Reproduced with permission from Ōmiya Library, Ryūkoku University, Kyoto, Japan.

Daniel Arasse. ${ }^{4}$ It will seek to address Cheng's regret that "with regards

4 This research will essentially hinge upon the theories developed in: François Cheng, Vide et plein, Le langage pictural chinois (Paris: Seuil, 1991); François Cheng, Souffle-Esprit (Paris: Seuil, 2006); Daniel Arasse, Histoires de peinture (Paris: Gallimard, 2004); Daniel Arasse, Le Détail (Paris: Flammarion, 1996). François Cheng (1929-now) is an eminent Sinologist who became member of the Académie Française in 2002. Daniel Arasse (1946-2003) worked as study director at EHESS (School of Social Sciences). As an art historian, he specialized in Renaissance and Italian art. 
to its application in practical fields, the notion of void has never been studied in a systematic manner," 5 and fulfill Daniel Arasse's late wish to further explore the political dimension of vacuum and perspective. ${ }^{6}$ The techniques and concepts that nurture landscape painting and perspective will be examined to show how they apply to the instrumentalization of the

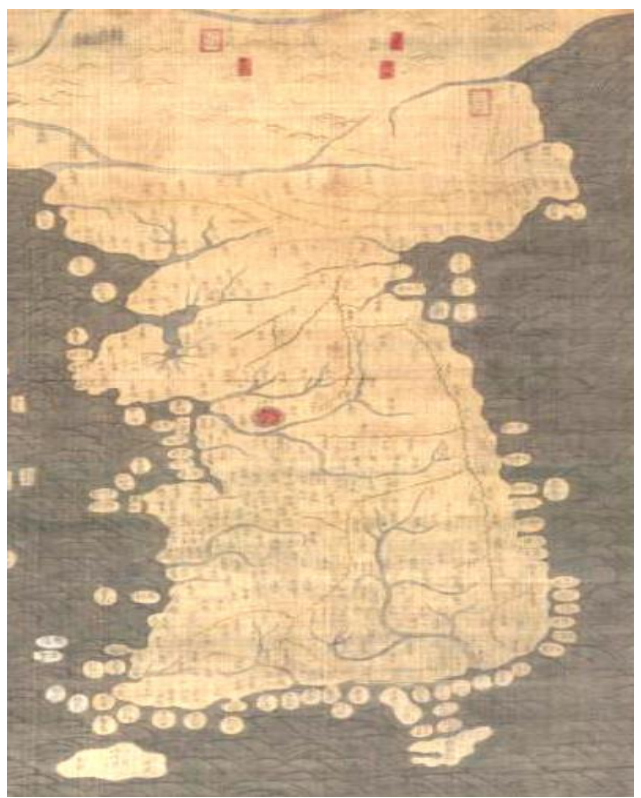

Detail of the Korean Peninsula inspired by the lost P'altodo (1400) on the Ryūkoku Kangnido, 1479-1485.

Reproduced with permission from Ōmiya Library, Ryūkoku University, Kyoto, Japan. $^{7}$

5 Cheng, Vide, 46.

6 Arasse, Histoires, 63; Arasse, Le Détail, 149-155.

7 Digital reproductions are also available at: "Reproduction of the Ryūkoku Kangnido," Busan Historical and Cultural Collections, accessed December 15, 2020, http://busan.grandculture.net/Contents/Index?local=busan.

Also available at: "Colored reproduction of the Ryūkoku Kangnido," Insitute of Korean Studies, Kyujanggak, accessed December 15, 2020, http://kyudb.sn u.ac.kr/book/view.do. 
Kangnido and Fine's maps. What the discussion will seek to bring to the fore is that far from being peripheral to their work, Yi Hoe and Fine's respective resort to landscape painting and perspective structure their maps. Not only do they make possible the polarity between science and ignorance, and the politically-motivated dialectics between secrecy and ostentation, but they also extend the meaning of their maps beyond conventional spatial and temporal benchmarks. The conclusion will establish a four-pronged typology of voids as instrumentalized on these maps, and potentially on others.

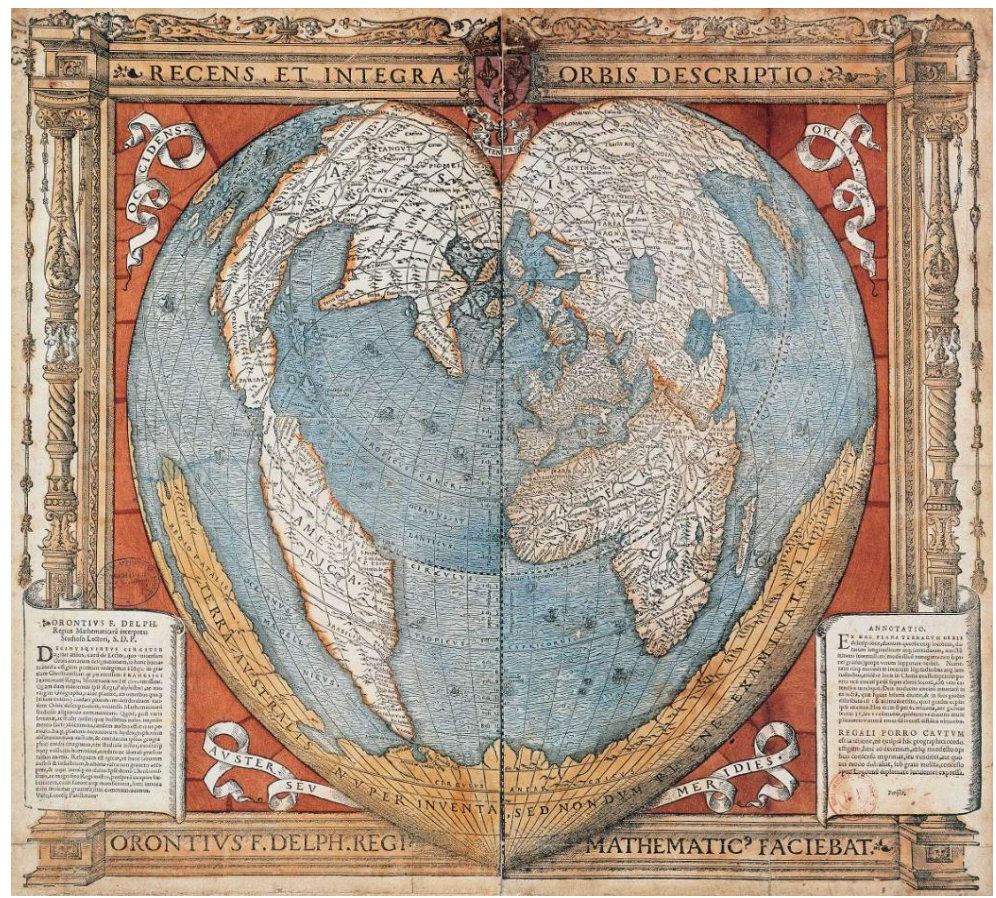

Recens et integra orbis descriptio $(51$ x $57 \mathrm{~cm})$, Oronce Fine, 1536.

Reproduced with permission from BNF, Cartes et Plans, Rés. Ge DD 2987 (63). ${ }^{8}$

8 "Recens et integra orbis descriptio," Oronce Fine, Bibliothèque nationale de France, accessed December 15, 2020, http://expositions.bnf.fr/lamer/grand/054.htm. 


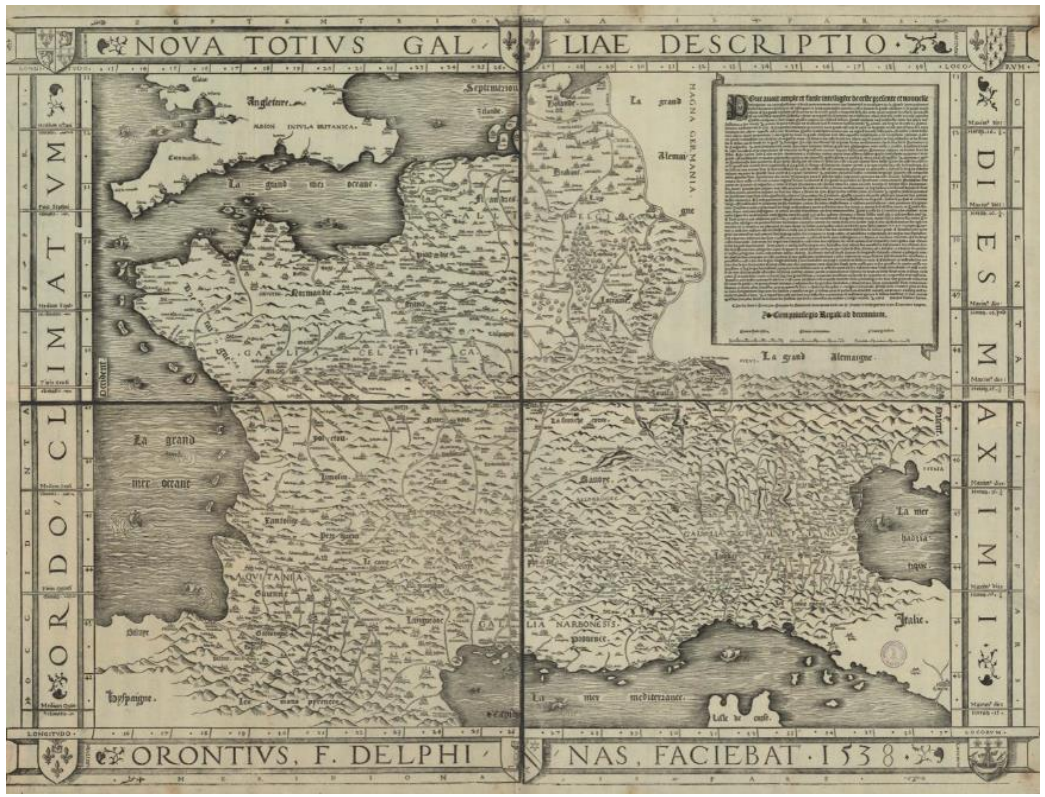

Nova totius Galliae descriptio (58 x $79 \mathrm{~cm}$ ), Oronce Fine, 1538 .

Reproduced with permission from Universität Basel, Kartenslg AA123, Switzerland. ${ }^{9}$

\section{The 1402 and Ryūkoku Kangnido and Oronce Fine's Maps}

In 1525, Oronce Fine drew what would be the first version of a series of five maps of France entitled the Nova totius Galliae descriptio ( 58 x 79 $\mathrm{cm})$. The 1525 and 1557 versions were lost, but the 1538, 1546, 1553 reeditions are respectively kept at Basel University, Leiden University and Bibliothèque nationale de France. All five versions were presumably printed from the same four woodcuts ${ }^{10}$ for Fine's scarce resources pre-

9 "Nova totius Galliae descriptio," Oronce Fine, Universität Basel, accessed December 15, 2020, https://www.e-rara.ch/bau_1/content/zoom/3946213.

10 Monique Pelletier, De Ptolémée à La Guillotière (XVe-XVI siècles). Des cartes 
vented him from updating coordinates he had nonetheless improved. ${ }^{11}$ Aside from preservation conditions, all three extant versions are almost identical. France, or rather Gaul, appears surrounded by the ancient divisions of the Roman Empire. The title and the Ptolemaic climates are in Latin, but the commemoration and some toponyms are written in French. According to the cartographer's commemoration, the map was intended to "generally describe and reform the longitudes and latitudes, and situation of the main places, coasts, rivers and mountains" 12 so as to please "all the mathematics' friends." 13 This scientific letter of intent is confirmed on his world map entitled the Recens et integra orbis descriptio (51 x $57 \mathrm{~cm}, 1536)$, which resorts to a single heart-shaped projection, whereas a simple trapezoidal projection is used on France map. The Hellenic geometric heritage conveyed by Ptolemy through both maps first meets the eye. But Fine also alludes to "the numerous observations from recent hydrographers." 14 This would indicate that the former cartographic tradition had to be combined with a second strand of sources -the contemporaneous explorations reported by argonauts on portolans. This epistemic duality permeates the linguistic field too since Fine used a bilingual nomenclature in Latin and French on France map. This happened at a time when Fine was appointed royal lecturer by Francis I in the first chair of mathematics at the recently created Collège de France (1530). Nine years later, the Villers-Côtterets ruling (1539) prohibited Latin in legal documents and converted French into the administration's official language. These initiatives were widely perceived as challenging Paris Uni-

pour la France, pourquoi, comment ? (Paris: CTHS, 2009), 22.

11 Gallois, "La grande carte de France d'Oronce Fine," 338.

12 Oronce Fine, "Légende de la Nova totius Galliae descriptio (1538)," in Lucien Gallois, "Oronce Fine et sa grande carte de France de 1525," Bulletin de l'Association de géographes français 99, 13e année (juillet-octobre 1936): 113.

13 Oronce Fine, "Légende de la Recens et integra orbis descriptio," in Lt-colonel Langlois, "Étude sur deux cartes d'Oronce Fine de 1531 et 1536," Journal de la Société des Américanistes 14-15 (1922): 93.

14 Fine, "Légende," 93. 
versity and the Church' monopoly on science and faith imparted in Latin. ${ }^{15}$ Reflecting this, a dual order emerges from Fine's work -Ptolemy and portolans; knowledge and power.

One century before Fine, Yi Hoe also drew a map of his kingdom, the P'altodo (1400), and a world map, the Kangnido (1402). Both were lost but somehow survived through other maps. According to academic consensus, the P'altodo served as a model for Yi Hoe when drawing the Korean peninsula on the 1402 Kangnido. ${ }^{16}$ As for the oldest extant version of the Kangnido, it is preserved at the Ryūkoku University and is therefore known as the Ryūkoku Kangnido. A nearly square silk roll of $164 \mathrm{x}$ $171,8 \mathrm{~cm}$, it was originally attached to a wooden rod. Kenneth Robinson estimated its dating between $1479-1485 .{ }^{17}$ Its cartographer remains unknown, as were those of the three later versions (Honkōji, Tenri and Honmyōji, circa 1560) probably also despoiled during the Imjin wars (1592-1598). Based on Robinson's assumption that the shapes and proportions of the 1402 Kangnido are preserved on the Ryūkoku Kangnido, ${ }^{18}$ this study will focus on these two versions. Surmising Yi Hoe's intentions proves difficult since his biography and the T'aean Yi Genealogies were embellished. ${ }^{19}$ What is verifiable, however, is that after passing the higher civil service examination in 1382, he held various posts under the Koryŏ and the Chosŏn governments. Exiled in Sunch'ŏn (1394), he returned to the capital (1402) where he was asked by his superiors Yi Mu and Kim Sahyŏng to make a world map. In the commemoration written by Kwŏn Kŭn (權近) -an official from the Ǔijŏngbu (議政府, State Council)- only two cartographic references are explicit -the

15 Marc Fumaroli, Les origines du Collège de France (1500-1600) (Paris: Collège de France, 1998), 3-108, 185-208.

16 Ledyard, "Cartography," 247.

17 Kenneth Robinson, "Chosŏn Korea in the Ryūkoku Kangnido: Dating the Oldest Extant Korean Map of the World (15th century)," Imago Mundi 59, Part 2 (2007): 177-192.

18 Robinson, "Chosŏn Korea," 185-188.

19 Kenneth Robinson, "Yi Hoe," 221-250. 
Shengjiaoguangbeitu (聲教廣被圖, circa 1330) and the Hunyijianglitu (混 一疆理圖, prior to 1392). ${ }^{20}$ With respect to the content of the map, Chinese capitals of historical and administrative significance are enumerated from right to left under the title. In addition to featuring 425 place-names for the sole Korean peninsula, the Ryūkoku Kangnido is the first Far Eastern world map including continents beyond the Confucian realm: the Arabic peninsula and Africa are easily recognizable but it also includes place-names from Europe as will be detailed below. Yet in the graphics of the commemoration and the painting itself, pride of place is given to China which visually occupies two thirds of the map. The accuracy of the Korean peninsula on the Ryūkoku Kangnido cannot be matched by Fine's inequal treatment of provinces and even less so by his approximate recourse to portolans. The Ryūkoku Kangnido's cartographer painted a realistically rugged peninsula where Fine traced an unrealistic rectilinear Atlantic coast. Just like France, Korea's surface seems increased to the detriment of its neighbors -except China. More surprisingly, considering that the Kangnido included the Azores, it pivoted Japan 90 degrees clockwise to the South of Korea, allegedly due to a prosaic lack of space on the silk roll. ${ }^{21}$ As for the rationale for making this map, Kwŏn Kŭn explains that the Kangnido' viewers can "know the world" and its patrons "get help in the work of government" 22 -scientific and political ambitions akin to Fine's.

\section{Literature Review: Absences and Presences}

The Ryūkoku Kangnido and Fine's maps have inspired many learned

20 Kwŏn Kŭn, "Commemoration of the Kangnido," quoted in Gari Ledyard, "Cartography in Korea," in The History of Cartography, ed. Catherine Delano Smith, Nathan Sivin, Cordell Yee, et al. (Chicago: J.B. Harley et D. Woodward, 1994), 245.

21 Ledyard, "Cartography," 247.

22 Ledyard, "Cartography," 245. 
glosses. This section will first review the main contributions in the literature. It will then argue that a comparative approach can help structure and further these analyses around a common dimension that has been, if not entirely ignored, at least widely toned down -painting techniques and their conceptual toolbox.

By silencing more than stating sources, Kwŏn Kŭn's commemoration has fueled speculations on other possible influences. As regards Chinese toponyms, Philippe Pelletier suggested a possible filiation from the Yuditu (與地圖, 1320), ${ }^{23}$ and Oh Kilsun stressed similarities with the Yuanjingshidadiandilitu (元經世大典地理圖, 1331). ${ }^{24}$ Even though it sought to take distance with Koryŏ, the nascent Chosŏn inherited from it a concern for administering its territory through maps. Han Youngwoo exemplifies this practice by referring to the Koryójirido (高麗地理圖), mentioned in the Liaoshi (遼史) and sent to the Liao court in 1002, or to the Odoyangyyedo (五道兩界圖, circa 1150). ${ }^{25}$ Beyond Korea, Bae Woosung conjectured that Yi Hoe could have had access to Gyoki-style maps (行基 図) -through the diplomat Pak Tonji (朴惊之) who went to Japan between 1398 and 1402. He thus "added a map of Japan”, as Kwŏn Kŭn laconically puts it. ${ }^{26}$ Besides, previous studies have shown that, courtesy of the Mongols who brought Arabic-Persian geographical knowledge to the Yuan court, the areas West of China are provided with 640 toponyms tran-

23 Philippe Pelletier, L'Extrême-Orient. L'invention d'une histoire et d'une géographie (Paris: Gallimard, 2011), 172.

24 Oh Kilsun, “Wŏn'gyŏngsedaejŏnjirido e naonŭn chimyŏng ŭi chosa wa Honil kangni yŏktae kukto chi to sŏyŏkchimyŏng gwaŭi pigyo," Han'gukkojidoyŏn'gu 2, no. 2 (2010): 99-100.

25 Han Youngwoo, "The historical development of Korean cartography," in The artistry of early Korean Cartography, ed. Han Youngwoo, Ahn Hwijoon, Bae Woosung (Honolulu: University of Hawai'i Press, 2009), 4-5.

26 Bae Woosung, "Joseon Maps and East Asia, Mapping the World: the Joseon Worldview as seen through old maps," in The Artistry of Early Korean Cartography, ed. Han Youngwoo et al. (Honolulu: University of Hawai'i Press, 2009), 57; Kwŏn Kŭn, “Commemoration,” 245. 
scribed in traditional Chinese characters from Mongol, Turkish, Persian, Arabic, Indian, Slav, Greek, Latin, Spanish and Catalan toponyms. ${ }^{27}$

The reasons for re-engaging a 600-year-old map and its exegeses will now be specified. As mentioned in the introduction, the plethora of entries and landmasses on the Ryūkoku Kangnido have been widely acclaimed as unmistakable signs of scientific precocity. ${ }^{28}$ To name just one, Africa is circumvented before Bartolemeu Dias's journey in 1488. In other words, the Ryūkoku Kangnido not only goes far beyond the Sino-centric doxa, but some of its content also predates the state of knowledge in Europe. Even though occasional errors and other anomalies such as the inflated size of China and Korea, the position of Japan south and not east of Korea have been noted, ${ }^{29}$ disproportionate attention has been paid to what lies on the map. And when the interaction between what went missing and what surfaces on the map was tackled, it was either imputed to a clumsy amalgam of cartographic traditions (from Koryŏ, Yuan China, Gyokistyle maps, geomancy and Arab-Persian geography) ${ }^{30}$ or to political motives. ${ }^{31}$ On the margins of these investigations, the general crossed influences between painting and cartography have been discussed by Ahn Hwijoon. ${ }^{32}$ Gari Ledyard ${ }^{33}$ and Kenneth Robinson ${ }^{34}$ stressed how later

27 Oh Kilsun, "Wŏn'gyŏngsedaejŏnjirido," 99; Angelo Cattaneo, "World Cartography in the Jesuit Mission in China. Cosmography, Theology, Pedagogy," in Education for New Times: Revisiting Pedagogical Models in the Jesuit Tradition, ed. Artur K. Wardega S.J. (Macau: Macau Ricci Institute, 2014), 77.

28 Oh Sanghak, "Honil kangni yǒktae kukto chi to," 91-109; Kenzheakhmet, "The place names," 141-160; Kenzheakhmet, "The Place Names," 106-125.

29 Bae Woosung, "Joseon Maps," 57; Oh Sanghak, "Chosŏnshidae ŭi ilbonjido wa ilbon inshik,” Taehanjirihak'oeji 38, no. 1 (2003): 33-34; Hirotada Kawamura, “川 村博忠, 近世絵図の地㘠性一 地図の向き一, ”地理科学 45 no. 3 (1990): 137138.

30 For a critical discussion on the Ryūkoku Kangnido's approximative integration of sources, see Oh Sanghak, "Chosŏnshidae," 32-47.

31 Choi Changmo, "Chosŏnshidae kojidoŭi arabia • ap'ŭrik'a ihae sogo," Han'gukkojidoyŏn'guhak'oe haksultaehoe (2012): 23-52; Short, Korea, 16-26.

32 Ahn Hwijoon, "Early cartography and painting," in The artistry of early Korean 
versions of the Kangnido included more Daoist elements and progressively adopted the mould of ch'ónhado maps. Applied to the Ryūkoku Kangnido proper, previous studies pointed out ornamental details ${ }^{35}$ or nuances in the coloring codes through spectrometric analysis. ${ }^{36}$ But aesthetic considerations have not given way to a thorough analysis of landscape painting as a possible structuring framework for interpreting the Ryūkoku Kangnido.

As regards the academic literature on Fine, three waves of critical analyses addressed his work. During his life, Jean Borrel and Pedro Nunes questioned the validity of his mathematical demonstrations but left his geographical record untarnished. ${ }^{37}$ At the turn of the $20^{\text {th }}$ century, Lucien Gallois' thesis and articles gave a more comprehensive appraisal of Fine as a polymath -in spite of all well versed in mathematics, geometry and geography- who could design and fix most of the tools required to deter-

Cartography, ed. Han Youngwoo et al. (Honolulu: University of Hawai'i Press, 2009), 133-155.

33 Ledyard, "Cartography," 254-267.

34 In support of the thesis that the Ryūkoku Kangnido is despiritualized, one could quote in extenso Kenneth Robinson who notes that "compared to the Ryūkoku Kangnido, the Honkōji Kangnido (...) include [s a] greater number of imagined lands derived from Daoist texts and ancient histories". Besides, Mt. Kunlun reappears on the Tenri and Honmyōji Kangnido which both include more Daoist imaginary places -copied from the 十洲記- than the Ryūkoku Kangnido and Honkōji Kangnido. Kenneth Robinson, "Daoist Geographies in Three Korean World Maps," Journal of Daoist Studies 3 (2010): 101-112.

35 Ahn, "Early cartography," 136-137.

36 Okada Yoshihiro, "Ch'ogojŏngmil hwasangch'ŏri e ŭihan Honil kangni yŏktae kukto chi to ŭi kwahakpunsŏk," Han'gukkojidoyŏn'guhak'oe haksultaehoe (2012): 86.

37 Jean Borrel, Confutatio quadraturce circuli libri ab Orontio Finc factoe, in Opera geometrica, quorum tituli sequuntur, Lyon, T. Bertellus, 1554 ; Pedro Nunes, De erratis Orontii Finai Regii Mathematicarum Lutetice Professoris, Coimbra, J. Barreira et J. Alvares, 1546. 
mine coordinates. ${ }^{38}$ Prior to being an artist, the Renaissance artifex was in effect "a producer of useful objects." 39 More recently, a collective publication delved into the various aspects of his work; namely, the propaedeutic status of mathematics, algebra, practical geometry and sundials. ${ }^{40}$ In particular, Jean-Jacques Brioist proceeded with a detailed examination of his cartographical methods. ${ }^{41}$ In comparing the latitudes and longitudes calculated by Martin Waldeseemüller, Fine and his successors (Jean Jolivet, Guillaume Postel and François La Guillotière), Monique Pelletier established that the accuracy of Fine's coordinates placed him among the best cosmographers in $16^{\text {th }}$ century Europe. ${ }^{42}$ Elsewhere, Pelletier also underlined the political and historical dimensions of Fine's work. ${ }^{43}$ However, mathematical and technical investigations have been implemented separately from the political aspects of Fine's maps. Similarly to the Ryūkoku Kangnido, analyses related to the cartographer's skills as an artist -drawings carved on woods in Fine's case- have been very limited: Gallois praises the adventitious adornments of the frame but Broc also

38 Lucien Gallois, De Orontio Finaeo gallico geographo (Paris: E. Leroux, 1890) ; Lucien Gallois, "La grande carte de France d'Oronce Fine," 337-348 ; Lucien Gallois, “Oronce Fine," 107-115.

39 André Chastel, "L'artiste," in L’homme de la Renaissance, ed. Eugenio Garin (Paris: Seuil, 2002), 257.

40 Alexander Marr, The worlds of Oronce Fine (Donington: Shaun Tyas, 2009); see also Angela Axworthy, Le mathématicien renaissant et son savoir, Le statut des mathématiques selon Oronce Fine (Paris: Classiques Garnier, 2016).

41 Jean-Jacques Brioist, "Oronce Fine and cartographical methods," in The worlds of Oronce Fine, Mathematics, Instruments and Print in Renaissance France, ed. Alexander Marr (Donington: Shaun Tyas, 2009), 137-155.

42 Pelletier, De Ptolémée, 17-19.

43 Monique Pelletier, Cartographie de la France et du monde de la Renaissance au Siècle des lumières (Paris: Éditions de la Bibliothèque nationale de France, 2002), 11 ; Isabelle Pantin, "Oronce Fine's Role as Royal Lecturer," in The worlds of Oronce Fine, Mathematics, Instruments and Print in Renaissance France," ed. Alexander Marr (Donington: Shaun Tyas, 2009), 16. 
mocks an oronymy resembling molehills. ${ }^{44}$ Most importantly, the manner in which the geometrics of perspective could embrace Fine and Francis I's political agenda has not been fully appreciated.

\section{Landscape Painting and Perspective as Cartographic Keys}

Examining the philosophical background to Buddhist and Taoist landscape painting shanshuihua (山水畫), François Cheng translates the ideogram $l i$ (理) as "principle or internal structure." The artist's task is therefore "less about describing the external aspects of the world than about capturing the internal principles that structure all things and connect them to each other." 45 Often opposed to these traditions, Confucianism and its approach to geography dili (地理, which Pelletier translates as "ordering of the earth") ${ }^{46}$ follow the literal meaning of $l i$, "to put (things) in order." This definition presupposes that things were not in order, and should be rectified (to use the Confucian terminology) and reverted into a normative order. Whether $l i$ refers to an ontological Taoist notion or a Confucian precept, both interpretations overlap when they tell of a gap between material contingencies and immaterial aspirations. At the Tohwasŏ (圖畫署), where artists indifferently devoted themselves to cartography and landscape painting imported from China since Koryŏ, ${ }^{47}$ the painters turned cartographers might have more or less consciously resorted to an array of shanshuihua techniques and concepts to serve the interests of their freshly enthroned Neo-Confucian patrons. In a more ceremonial vein, "landscape

44 Numa Broc, "Quelle est la plus ancienne carte 'moderne' de la France ?," Annales de Géographie 92, no. 513 (1983): 516; Lucien Gallois, "Un géographe dauphinois : Oronce Fine et le Dauphiné sur sa carte de France de 1525," Recueil des travaux de l'Institut de géographie alpine 6, no. 1 (1918): 3-13; Gallois, "La grande carte de France d'Oronce Fine," 347.

45 Cheng, Souffle-Esprit, 155.

46 Pelletier, L'Extrême-Orient, 73.

47 Ahn, "Early Cartography," 142. 
depictions were also part of the documentary painting kyehaedo used to record and celebrate political events such as the inauguration of provincial governors or civil service examinations." 48

Although expressed differently, the relation between painting, cartography and politics in Europe is no less eloquent. Florence, the birthplace of perspective (1420-1450), was simultaneously at the cutting edge of cartography. According to Arasse, the relation between perspective and cartography is intimate for both delivered measured representations of space. ${ }^{49}$ Perspective also acquired political overtones from its very inception. In order to distinguish himself from his rival Paolo Strozzi who magnified his power through gothic paintings, Cosimo de' Medici chose the sober style of perspective articulated by the principles of sobrietas and res publica in Florence public chapels. The emerging sponsors of perspective were using it against their political rivals and against the Church; for perspective, and the rationality it drew on, became the symbolic form of a de-theologized world. ${ }^{50}$ Once summoned to "hide the secret of the Incarnation within the visible scope of the Annunciation", ${ }^{51}$ the painters' expertise in perspective now embraced the vision of their new employers -political leaders. Francis I, who famously brought Italian painters to his court, is portrayed in a 1534 illumination in perspective ${ }^{52}$ as patron of the arts and letters, surrounded by his most conservative advisors all in favour

48 Short, Korea, 17.

49 Arasse, Histoires, 60-68.

50 Arasse, Histoires, 65.

51 The paintings illustrating this idea are The Annunciation (1344) by Ambrogio Lorenzetti; The Annunciation (1445) by Domenico Veneziano; and The Annunciation (1470) by Piero della Francesca. Arasse stresses that "perspective was not at all a constraint to painters, but rather an instrument they toyed with and to which they could give different meanings". Arasse, Histoires, 76-83.

52 Jean Clouet, "Antoine Macault lisant sa traduction au roi François Ier et à sa cour, Les trois premiers livres de Diodore de Sicile," RMN Grand Palais, Domaine de Chantilly, Musée Condé, accessed December 15, 2020, https://www.phot o.rmn.fr/archive/01-004920-2C6NU0GQF8JP.html. 
of the Papacy and Charles V after the Cambrai Treaty (1529). But, beyond this idealized portrayal where everything is luxury, calm and wisdom, peace is but a respite allowing for the conduct of a secret diplomatic guerrilla to counter the emperor's [Charles V] schemes. ${ }^{53}$ Whether through geometry or $l i$, paintings are suffused with an unspoken order. But lest it is to "too full" or "too accomplished," 54 the shanshuihua painter always keeps an element of void from his originally blank roll. And, following Alberti's advice whereby the presence of voids prevents pictorial chaos, ${ }^{55}$ the perspective painter constructs an image in three dimensions whose depth conceals as much as it suggests.

In oriental landscape painting, blanks and strokes are the pictorial illustrations of couple concepts such as $x u$-shi (虚-實, empty-full), yin-xian (隐-现, invisible-visible), wu-you (无-有, not have-have). ${ }^{56}$ Non-painted voids are therefore far from being unthought. There are instead an "eminently dynamic and active element," the "ultimate place where transformations occur". ${ }^{57}$ Insofar as an analogy may be attempted, vanishing points and lines alike, existing data can be "hidden within the visible," while "the unfigurable surfaces from the figure, the inexpressible from the speech, the immensity from the measure." 58 Though visually expressed, perspective is the result of an intellectual operation and addresses the mind of its viewers. Hence a certain level of abstraction required in the process: "one has to be able to imagine the world to produce a map, yet any map that seeks to describe the world is ipso facto an invitation to imagine it." 59 This back-and-forth oscillation from mind to map is also re-

53 Edith Garnier, Guillaume du Bellay, l'ange gardien de François I ${ }^{e r}$ (Paris: Félin, 2016), 235-236.

54 Cheng, Souffe-Esprit, 25.

55 Leon-Battista Alberti, De la peinture, trans. Claudius Popelin (Paris: A. Lévy, 1868), 154.

56 Cheng, Vide, 53-84

57 Cheng, Vide, 45.

58 Arasse, Histoires, 78-82.

59 Gilles Tiberghien, Finis Terrae. Imaginaires et imaginations cartographiques (Par- 
flected in the etymology of the pictogram $t u$ (圖, K. to) which literally means a "plan" or a "drawing" but which can also happen to signify "to estimate," "to calculate," "to try for" and "to scheme." 60 In French, the words géographie and carte for "map" came to be adopted in 1525 and $1532,{ }^{61}$ at the height of Fine's career, which also tends to prove that new practices and functions required new words. But some of these acceptations were already engraved in the Latin term Fine used in the titles of his maps -descriptio: "reproduction," "drawing," "outline," "delimitation," "setting of functions," "definition in philosophy," and of course "description." 62 In other words, maps are, as the word geography suggests, both a drawing and a writing of the world. They illustrate concepts which have been forged, and must be traced, in a wider para-text. In that sense, the enmeshment between $t u$ (images) and $s h u$ (texts) ${ }^{63}$ may find Western resonances in the rich acceptations of the term descriptio.

Having established this, the below sections will consist of demonstrating that Yi Hoe's $t u$ and Fine's descriptio enable them and their patrons to reach their goals -showing scientific updates and hiding ignorance, lauding the past while anticipating future events, feigning adherence to the status quo while devising revisionist policies- with all the more efficiency that they were assisted by landscape painting and perspective.

\section{Scientific Links and Gaps}

Authoritative studies have lauded Yi Hoe and Fine's maps for their contribution to scientific progress. Yet, in spite of their claims to portray

is: Bayard, 2007), 45-46.

60 Léon Wieger, Chinese characters, Their origin, etymology, history, classification and signification (New York: Dover Publications, 1965), 686.

61 Jean Dubois, Henri Mitterrand and Albert Dauzat, Dictionnaire étymologique (Paris: Larousse, 2007), 138-361.

62 Félix Gaffiot, Dictionnaire Latin-Français (Paris: Hachette, 1990), 505.

63 Brotton, A History, 124. 
integrated lands and regions or an integra orbis descriptio, quite a few are either misrepresented or elided thanks to painting techniques. The first operation when considering a drawing in perspective, which Fine then carved on printing woodblocks, is not to determine the vanishing point but to set the framing, ${ }^{64}$ which evidently determines what the viewer sees. Appealing to the eyes of the connoisseur as well as the casual cartophile, Fine's heart-shaped projection embraces the latest scientific breakthroughs as well as its biases. Fine is first of all indebted to Ptolemy in as much as he perpetuates the orthonormed system which consists, through a graticule, of defining a place as a geometrical point resulting from the intersection of two lines -a meridian and a parallel- and to determine its longitude and latitude in a map subsumed into a 360-degree circle. ${ }^{65}$ On France map, Fine resorts to a simple trapezoidal projection, whereas on his world map he uses a more elaborate single heart-shaped projection already tested by three contemporary cartographers ${ }^{66}$ but also bequeathed by Ptolemy. The ecumene -a three-pronged landmass composed of Europe, Asia and Africa- is thus extended into a world map featuring the fourth continent -America as designated for the first time in Waldseemüller's map (1507)- without discontinuity between its Northern and Southern parts as was the case until then. ${ }^{67}$ In an oblique allusion to the portolans that emerged in Europe by the end of the $13^{\text {th }}$ century, Fine admits having streamlined his maps "according to numerous observations from recent hydrographers." ${ }^{\prime 68}$ Enriched by this tradition, his world map marginalizes the view that the Indian Ocean was a closed sea surrounded by Africa, Asia and the Austral land. Likewise, he includes the Terra francesca nuper lustrata, or Baccalear region, recently discovered by Verra-

64 Alberti, De la peinture, 124.

65 Tiberghien, Finis Terrae, 91-92.

66 Brioist, "Oronce Fine," 151.

67 Langlois, "Étude," 89.

68 Fine, “Légende," 93. 
zano in 1524 on behalf of the king of France. ${ }^{69}$ Fine thus depicts the world according to an updated state of science and discoveries France appears to contribute to.

Be that as it may, Fine's map-viewers are lured into seizing the whole world in one glimpse. They are slightly overhanging it since the meridians all converge towards a lowered North pole. This overlooking angle reduces but does not altogether manage to conceal an hyperinflated South Pole -Terra australis nuper inventa sed non dum plene examinata-, thus illustrating the erroneous conviction according to which the continental landmass in the Northern hemisphere had to be balanced by its Southern equivalent. Commonly thought to be significantly smaller than South America, North America appears in similar proportions to its counterpart because it is daringly merged with Asia at latitudes clearly below the Bering Strait. Contrary to Fine with Korea -Western cartography accurately localized Korea for the first time in Joan Blaeu's Atlas Maior (1662)-, ${ }^{70}$ the Ryūkoku Kangnido's cartographer manages to locate and name Falixi (法里昔, France), along with other European places -Alunia (阿鲁尼阿, Germany), Malixilina (麻里昔里那, Marseille or Barcelona). ${ }^{71}$ Unlike previous Arab maps, it gives a Southern, not Eastern, orientation to the Southern tip of Africa. ${ }^{72}$ But without disregarding the fact that when the 1402 Kangnido was drawn Europe knew hardly more of the world than mappae mundi cared to show, it makes important omissions such as America $^{73}$ and, as in Fine's case, Oceania. In the same subtractive vein, its continental bias dries up the earth of the Pacific and Atlantic Oceans, the list of capitals dissimulates and embellishes unexplored Northern latitudes, while both poles are conveniently framed out.

69 Langlois, "Étude," 88.

70 Short, Korea, 36-47.

71 Kenzheakhmet, "The Place Names," 107.

72 Oh Sanghak, "Honil kangni yŏktae kukto chi to ŭi ch'oegŭn tamnon gwa chido ŭi chaep'yŏngga," Kukt'ojirihak'oeji 50, no. 1 (2016): 131.

73 Kenneth Robinson, "Gavin Menzies, 1421, and the Ryūkoku Kangnido," Ming Studies 61 (April 2010): 56-70. 
Much as French and Korean lacunae reflect the uneven progress of geography as well as the difficulty in harmonizing heterogeneous cartographic epistemes, ${ }^{74}$ the visualization of lands unexplored by their cartographers -Fine only went to Italy a year before drawing France map while Yi Hoe went to China five years after drawing the 1402 Kangnidois ultimately made possible by painting techniques which doctor scientific dubiety. Fine seizes the orb geometrically, but pictorially vanishing lines induce vanishing data which, as perspective theories put it, are "hidden within what can be seen:" 75 since the map is centered on a meridian tangent to Europe and Africa's Western coasts, the unfamiliar territories of America and Asia conveniently disappear into a fleeting rotundity at the horizon of which Korea is not named. Likewise, the Ryūkoku Kangnido's cartographer inflates or deflates chosen areas in an interplay of microcosms and macrocosms whereby, in a typical landscape painting vein, further away places can appear closer than those at the fore ${ }^{76}$ the Korean and Arabic peninsulas are inflated to the detriment of Japan, Africa and an Indian subcontinent conspicuous by its absence.

Beneath asymmetries and nescience, an assiduous examination of unrepresented elements also tells of tenuous exchanges. By juxtaposing Gangem and Malacha, Fine, in Ptolemy's footsteps, erases or rather merges India into Eastern antipodes. More confusingly, its toponym appears twice (intra-Gangem and extra-Gangem) on his world map. Although India was known by Koreans through Buddhism since the $4^{\text {th }}$ century at least, its absence on the Ryūkoku Kangnido is also deriving from Ptolemy through the intercession of Arabo-Persian maps. ${ }^{77}$ Here, para-

74 For a critical discussion on Fine's difficulties with portolans, see François de Dainville, "Cartographie historique occidentale," Annuaire 1969-1970, École pratique des hautes études. 4e section, Sciences historiques et philologiques (1970): 524. For a critical discussion on the Ryūkoku Kangnido's approximative integration of sources, see Oh Sanghak, "Chosŏnshidae," 32-47.

75 Arasse, Histoires, 83.

76 Cheng, Vide, 101.

77 Oh Sanghak, "Honil kangni yǒktae kukto chi to,” 119. 
doxically, it is a visually missing element and a cognitive gap which point to epistemic links. Eurasian exchanges are also patent on an astronomical map -Position of the Heavenly Bodies in their Natural Order and their Allocated Celestial Fields - which includes Greek zodiac signs transcribed in Chinese. ${ }^{78}$

Off the maps, other transmissions occurred in the opposite, westward direction. To determine coordinates and to design tools himself -epicyclic planetary clock, ivory dial, sundials and a méthéoroscope (an astrolabe modified by adding a compass)-, Fine benefited from Far Eastern technical inventions -compass, equatorial torquetum (Guo Shuo Jin, 1270)incremented by Arab sciences -astrolabes. ${ }^{79}$ In a rare occurrence, Fine even admits to having perused a manuscript in "Arabic tongue" which enriched his study of burning mirrors De speculo ustorio (1551) and his associated interest in perspective. ${ }^{80}$ A century earlier, these instruments were no secrets to Koreans who had refined their own equivalents -the kanŭi (簡儀) established Seoul's latitude with a margin of error of one decimal; ${ }^{81}$ the injiǔi (印地儀) measured latitudes and distances; ${ }^{82}$ and the kyuhyŏng (窺衡) improved triangulation calculations. Nevertheless, their applications tended to serve astronomy and rituals ${ }^{83}$ rather than cartography proper, thus eluding once again the visible scope of the Ryūkoku Kangnido. Similarly, the exactitude of odometers like kirigoch'a (記里鼓 車) and posuch'ǒk (步數尺) were used for cadastral plans, road surveys and distances between cities which, as far as the Ryūkoku Kangnido is

78 Brotton, A History, 116-117.

79 Jérémie Eyssette, Le Déroulement des Mondes, l'instrumentalisation cartographique du néoconfucianisme en Corée et de la Renaissance en France ( $X V^{e}$ XVI siècles) (Paris: L'Harmattan, 2020), 101-130.

80 Sven Dupré, "Printing practical mathematics", in The Worlds of Oronce Fine, ed. Alexander Marr (Donington: Shaun Tyas, 2009), 70-72.

81 Ledyard, "Cartography," 288.

82 Che Honggyu, "Map commentaries," in Old Maps of Korea, Han'guk ko chido, ed. Yi Ch'an (Seoul: Han'guk Tosogwanhak Yon'guhoe, 1977), 227.

83 Bae Kichan, Le roi Sejong le Grand (Séoul: Diamond Sutra group, 2001), 78-79 
concerned, are relatively well rendered for China and Chosŏn, but much more inconsistent as the subjective drudgery of merging cartographic traditions takes over non-Confucian territories.

Whereas Fine's maps and the Ryūkoku Kangnido are often taken as window cases of their advanced state of knowledge, it is a common mistake and asymmetries which point to invisible connections: they shared the Ptolemaic, India-free heritage while the Korean cartographer left mostly untouched technical devices Fine could not dispense with. Contrasting with bona fide voids, others were soon invested with political objectives which landscape painting and perspective managed to display or dissimulate.

\section{Instrumentalizing Spatial and Temporal Voids}

The frame chosen in the Nova totius Galliae descriptio whereby France only occupies half the space is presented as a reminiscence of France former political unit -Gaul. Broc highlights this diachronic perspective as follows: "it not only features the France of the Valois dynasty, but also the left bank of the Rhine river, Switzerland, Northern Italy up until the Adriatic, Central Italy until Pisa and Roma. The chosen limits are those of Gaul, or rather the Gauls (Cisalpine, Transalpine, Belgium), and not those of $16^{\text {th }}$ century France." ${ }^{\text {"4 }}$ Pelletier specifies this lineage by reminding that in his translation of The Gallic Wars (1485), Robert Gaguin "uses indifferently Gallia and Francia, Gallus and Francus to affirm the continuity, that seems to him essential, between Gaul and what was then France". ${ }^{85}$ In drawing a Gaul-France heir of the Roman Empire, Fine advocates a form of historical legitimacy made even more explicit in Commentaires de la guerre gallique (1520) where the lives of Julius Caesar

84 Broc, “Quelle est la plus ancienne carte 'moderne' de la France ?," 515.

85 Pelletier, Cartographie, 11. 
and Francis I are compared. ${ }^{86}$ On France map, this historical parallelism is perpetuated by a bilingual nomenclature in Latin and French. But it is Latin that is given prevalence on the map, mounted as it is within four strips all written in Europe's lingua franca: on top, the title (Nova totius Galliae descriptio); at the bottom, the signature and date of confection (Orontius F. Delphinas Faciebat 1538); on the left, the Ptolemaic climates (Ordo Climatum); and on the right, the duration of the longest day (Dies Maximi). These strips are all doubled with their respective cardinal directions, latitudinal and longitudinal coordinates. Within that frame, scriptural indications in Latin can be divided into the ancient divisions of the Roman Empire (Gallia Narbonensis, Gallia Cisalpina, Gallia Transalpina, Gallia Belgica, Gallia Celtica), ethnonyms and toponyms. Latin therefore adds historical depth to scientific authority but it also mirrors a political vision.

Under the pax romana the concept of world order derived from an association between the Gladius swords of the Empire and the Papacy. Inasmuch as Renaissance drew inspiration from a Latin model, the ideal European monarch was supposed to act as "the vicar of God and Christ on earth like Popes and Emperors before him." "very Christian King"88 in Fine's address still cared to translate this universal morality into concrete policies. Through the $18^{\text {th }}$ August 1516 Concordat of Bologna, the Papacy was entitled to manage the Church of France incomes and to veto any appointment made by the king, thus acknowledging the primacy of the Papacy over the Church of France. Besides, after losing the wars of the League of Cognac (1526-1530) -which sealed an alliance between Francis I and Pope Clement VII- the king of France, as a token of truce, was reluctantly drawn into marrying Eleonore,

86 Pantin, “Oronce Fine's Role," 16.

87 Sébastien Nadiras, "1308. A l'égal du pape et de l'empereur: le roi de France à Lyon", in Histoire mondiale de la France, ed. Patrick Boucheron (Paris: Seuil, 2017), 197.

88 Fine, "Légende," 93. 
the Emperor Charles V's sister. These two instances converge to show that Fine's map strives to echo the past so as to overplay Francis I's adherence to the status quo and placate suspicions from his main rivals -the Pope and Charles V.

On the Ryūkoku Kangnido, China's centrality is matched by the cartographer's insistence on shredding it in a venerated past. The Middle Kingdom radiates at the center of the "four seas" 89 which the Shangshu (尚書, $10^{\text {th }}$ century B.C.) used as cardinal points. A list of Chinese capitals of historical and administrative significance overhangs the depicted world. Interestingly enough, the toponymy in China itself is contemporary to the dynasty which integrated Neo-Confucianism as the ruling ideology and transferred it to the Koryŏ King Ch'ungnyŏrwang (1274-1308) -the Yuan. Replicating Yi Sŏnggye's adoption of the suzerain calendar zhengshuo (正朔), Kwŏn Kŭn dates his map “in the fourth year of the Jianwen era", ${ }^{90}$ the second emperor of the Ming dynasty and grandson of its founder Hongwu. Situating Chosŏn within Chinese spatial and temporal coordinates, the 1402 Kangnido was at some level marking the investiture of Chosŏn within "the Confucian ritualized world order of the tribute system chaogong (朝貢)." " 11 Inequal hierarchical status is therefore displayed with corresponding proportions. Gravitating around an unparalleled China, the size of Chosŏn -which sent three annual embassies to Ming China throughout the $15^{\text {th }}$ century- is doubled while Japan, where a non-Confucian Daimyō reigned, is dwindled by half. Still a Chinese province at the time of the 1402 Kangnido, Annan (安南) -Vietnam's administrative nomenclature since the Song dynasty- is absorbed into a China bordering on Asia. In this regional order, the celestial mandate tianming (天命) was bestowed upon the ruling family -in modern terms, the state

89 Kwŏn Kŭn, “Commemoration,” 245.

90 Kwŏn Kŭn, "Commemoration," 245.

91 Cha Hyewon, "Was Joseon a Model or an Exception? Reconsidering the Tributary Relations during Ming China," Korea Journal 51, no. 4 (Winter 2011): 34. 
family guojia (國家). ${ }^{92}$ This analogy between familial and political structures signified that just like filial piety xiaodao (孝道) commanded obedience to the elderly, a vassal kingdom was not entitled to question his suzerain as stipulated by the foreign policy axiom yixiaonida (以小逆大), or « a small nation shall not attack a bigger one ». By invoking history, the Ryūkoku Kangnido and Fine tend to legitimize and adhere to a form of status quo. Yet more subversive elements also lie in the folds of the maps.

Pelletier notes that France map feeds on the Renaissance undercurrents that glorify Gaul; but at the same time, they "discredit the medieval dismemberment of Louis the Pious' [Charlemagne's son] empire,"93 thus alluding to a more recent past and indirectly calling for action. The transgressive nature of visual representations is elucidated by Arasse who, elaborating on Alberti's De pictura, signals that the mathematical discourse of perspective should reflect the princely discourse and, as such, refrain from giving away too many details. Visual clarity is conducive to persuasive efficiency and in the process of selecting information, new values can be forged. ${ }^{94}$ When applied to Fine's maps, this input of perspective theory exposes the weakness of the status quo narrative. As regards the disputed frontier between France and Italy, it was composed on the French side of the Dauphiné, Savoie and Provence provinces. However, on France map, only Fine's native Dauphiné is relatively accurately represented while Savoie, strategically the most sensitive area, "is very poorly treated." 95 This inequality of treatment cannot be imputed to mere ignorance since Fine, accompanying the king, visited this region and Piedmont where he was consulted on constructing fortifications. More telling of his intention to misrepresent what constituted a ceaselessly disputed frontier, Fine drew a map of Dauphiné, Savoie and Piedmont in

92 Christofer Schipper, "Le chinois," in Tour du monde des concepts, ed. Pierre Legendre (Paris: Fayard, 2013), 175.

93 Pelletier, De Ptolémée, 20.

94 Arasse, Le Détail, 154-155.

95 Gallois, "Un géographe dauphinois," 16. 
1543 and, rather than adjoining it to France map, offered it to the king on a separate exemplary only published a decade later in such a small format that it was almost illegible. ${ }^{96}$ As in the classical Renaissance painting (compositio), the balance between the diversity of visual elements (varietas) and their intervals (vacuum) articulates the painting but also subtly hierarchises it. ${ }^{97}$ On Fine's map, this translates into granting France a greater status in the regional order. The Eastern flank of the country spreads eastward beyond the mistake in longitudinal calculation that would deprive France of $20 \%$ of its territory a century later. This liberty materializes in the fact that Fine's oronymy is overstepping borders beyond what the Italian Republics would have consented to. Drawing on Alberti's theory of contours, Fine conceals this territorial gain by tracing outlines "in an almost invisible manner." 98 Similarly, Fine leads his mapviewers to believe that further up North the Eastern border stretches until the Rhine river -indicated, like other rivers, by a double stroke- while in fact it includes at most Barrois, a suzerainty of the king of France on the left bank of the Meuse river. Observing that France dimensions are hypertrophied is another way of stating that its neighbors are undersized. The frame of France map excludes from its scope 3/4 of Espaigne (seemingly spelled Byspaigne), Angleterre, Grand Alemaigne and Italie's surfaces. As a reminder of current conflicts, these are named, for the occasion, in a language already competing with Latin for the status of diplomatic lingua franca -French. Charles V's territories, which since the 1494 Tordesillas Treaty spanned more or less half the globe, are not mentioned on Fine's world map. They are only gratified with a modest Espaigne in the bottom left corner of France map where Fine chooses to append his key on Grand Alemaigne, cartographically stamping on German grandeur.

From the $18^{\text {th }}$ century onwards, as Kim Seonmin suggested, "the Tumen and Yalu Rivers were a political space where the hierarchical tribu-

96 Gallois, "La grande carte de France d'Oronce Fine," 347.

97 Arasse, Le Détail, 152.

98 Alberti, De la peinture, 139. 
tary relationship that existed between the Qing and Chosonn courts could be visualized." 99 Indeed, diplomatic borders appeared for the first time on Mukedeng's Sketch of Mt. Paektu and the Sino-Korean border (1712) in a ch'ónhado atlas ${ }^{100}$-and coincidentally on Jacques Cassini's Carte de France (1718). Though spheres of allegiance were just as important in the $15^{\text {th }}$ century, matters were cartographically less linear. This is reflected in the full and abbreviated forms of the map's title. The Yuan dynasty progressively dropped the appellation Huayitu (華夷圖), which discriminated between China and Barbarians, and described instead Hunyitu (混一圖, amalgamated worlds). ${ }^{101}$ The prefix hun (混, K. hon) is kept in the full title (混一疆理歷代國都之圖), which poses the question of a hierarchical re-ordering in this new amalgamated configuration. This is confirmed by the abbreviated denomination of the Kangnido (疆理圖), which literally translates as "map ordering territories", not diplomatic borders. In the pictogram jiang (疆, K. kang), the radical on the left part represents a bow with a handle (弓) in the middle, and in its most ancient form this bow can be bent or vibrate. ${ }^{102}$ The bow itself shelters a territory (土) while the right part of the pictogram is composed of the character three (三) between the lines of which two fields (田) are inserted. ${ }^{103}$ But the brush strokes meant to represent delimitations among territories in the pictogram are not replicated on the map for Chosŏn's eight newly revamped provinces ${ }^{104}$ or between Chosŏn, China and the non-Confucian world.

Building on Robinson's research, Short argues that the Ryūkoku Kangnido "is a world map with three levels of accuracy: at the center is an up-to-date picture of the administrative and military geography of Ko-

99 Kim Seonmin, "Hunchun, the Qing-Chosŏn Borderland in the Eighteenth Century," International Journal of Korean History 21, no. 1 (February 2016): 186.

100 Pierre Singaravélou, Fabrice Argounès, Le monde vu d'Asie, Une histoire cartographique (Paris: Seuil, 2018), 75.

101 Han, "The historical development of Korean cartography," 6.

102 Wieger, Chinese characters, 222.

103 Wieger, Chinese characters, 29.

104 Robinson, “Chosŏn Korea,” 178-179. 
rea; in the next ring are clumsier, more anachronistic depictions of China and Japan; and finally, the rest of the world forms a hazy outer ring". ${ }^{105}$ Drawing a parallel between this depiction and the theoretical apparatus of landscape painting is useful for defining more accurately the interrelations between the three areas of the map. As a substitute for vanishing perspectives, Cheng notes that landscape painting also expresses "distances" through three internal sections: three mountain ranges are separated by empty spaces, suggesting an incommensurable space and inducing the viewer to take a qualitative leap from one to another. ${ }^{106}$ To put it even more succinctly, "the void fosters interactions between space and time." 107 Following this line of interpretation, the relatively empty spaces in place of brush strokes for borders in the Ryūkoku Kangnido's tripartite structure do not separate an up-to-date Chosŏn, a toponymic Yuan China, and areas beyond Confucian landmarks as much as they interconnect them. It is therefore necessary to nuance Choi's analysis according to which "empty spaces" only characterize the "external world" (i.e.: the non-Confucian world). ${ }^{108}$ Empty spaces are also located not without but within what he calls the "internal world" (i.e.: the Confucian world), and more specifically between China and Korea.

To separate the two political entities that were Ming China and Chosŏn Korea, Yi Hoe and the Ryūkoku Kangnido cartographer drew a notoriously imprecise Northern area. ${ }^{109}$ In the Northern buffer zone, Robinson notes that no information is available on Jurchen villages located between China and Chosŏn ${ }^{110}$; and the seventeen army bases non identified on the Ryūkoku Kangnido are all located in the two Northern provinces of

105 Short, Korea, 5-6.

106 Cheng, Vide, 103.

107 Cheng, Vide, 67.

108 Choi, “Chosŏnshidae kojido,” 38-40.

109 All the quoted literature on the Kangnido touches upon the Northern area whose main interpretations are provided by Gari Ledyard (1994), Kenneth Robinson (2007) and Oh Sanghak (2016).

110 Robinson, “Chosŏn Korea," 187. 
Hamgyŏng and P'yŏngan. ${ }^{111}$ While Yi Hoe could accurately locate remote places across the Eurasian landmass, why would an oftentimes surveyed area depart from realism? There is a misinterpretation in considering that empty spaces equate to places of lesser value necessarily situated outside the Confucian realm. The reluctance to characterize the Northern frontier as an empty space might be explained by the fact that its relative size on the map is small and therefore appears inconsequential or, at any rate, less empty that the vast areas spanning the non-Confucian world. But there is something qualitatively distinct from Jia Dan (賈耽)'s shrinking operation suo (缩) $^{112}$-used in oriental cartography in lieu of scales- since the Northern area is "over-shrunk" in comparison to an otherwise overblown peninsula. "The art of not showing everything" (yin-xian) expressed in landscape painting with "the interruption of strokes (...) and partial or total omissions" 113 finds a new expression on the Ryūkoku Kangnido. The plethora of toponyms on the Korean peninsula and the cartographer's meticulousness reach their limits between the river Chŏngch'ŏn and its Northern parallels formed by the Yalu and Tumen rivers: the Liaodong plains is abnormally compressed; the Yalu and Tumen rivers' estuaries are located too south; and an inexistent tributary is added to the Yalu river which is drawn horizontally whereas its orientation should be north/east-south/west. ${ }^{114}$

The geopolitical context sheds light on these cartographic imprecisions. Jurchen attacks notwithstanding, Yongle (r. 1402-1424) established the Jianzhou Guard in 1403, Tianshun (r. 1457-1464) reinforced military strength on the outer rings of the Empire, and the Tongp'alch'am (東八站, East Eight Posts) were reconstructed in the late $15^{\text {th }}$ century. ${ }^{115}$ On the

111 Robinson, "Chosŏn Korea,” 181.

112 Linda Rui Feng, "Can Lost Maps Speak? Toward a Cultural History of Map Reading in Medieval China," Imago Mundi 70, Part 2 (2018): 172.

113 Cheng, Vide, 85.

114 Ledyard, "Cartography,” 291.

115 Lee Jungshin, "Koreans' Perceptions of the Liaodong Region During the Chosŏn Dynasty," International Journal of Korean History 21, no. 1 (February 2016): 60- 
other side of the front, the outposts of Kyŏngsŏng (1356), Kyŏnghŭng (1398) and Kanggye (1400), the Yukchin (六鎮, Six Fortified Outposts) and the Sagun (四郡, Four Counties, 1433-1443) were incorporated into Chosŏn, while Sŏngchong (r. 1469-1494) ambiguously combined farming and military policies along the Yalu river. On the Ryūkoku Kangnido, the partially updated information and distortions are a measure of the topicality of issues that invalidates the overdone dichotomy between an anachronistic outside world and an updated inside world. In fact, the differentiated treatment of data within the inside world can be considered as an interpretative key that connects the inside to the outside worlds and reveals the underplayed tensions between Chosŏn and its neighbors in a way that is analogous with Fine's doctored Eastern front.

\section{Conclusion}

This research stemmed from the observation that both Yi Hoe and Fine drew kingdom and world maps at a time when Neo-Confucian Chosŏn and Renaissance France underwent significant cultural and political transformations. Separate studies already noticed the political use of cartography in $15^{\text {th }}$ century Chosonn and $16^{\text {th }}$ century France. Building on them, this research strove to show that it is not only possible to compare the Ryūkoku Kangnido and Fine's maps, but that parallels could also highlight the significance of their respective painting techniques for deciphering the instrumentalization of cartography. Paradoxically, missing elements or voids allow for new comparative forays between Korean and French cartographies.

A first category of voids encompassed the epistemic and technological bridges that tenuously connected $15^{\text {th }}$ century Chosŏn and $16^{\text {th }}$ century

62; Liu Jing and Piao Yan, "Expansion, Contestation, and Boundary Making: Chosŏn Korea and Ming China's Border Relations over the Yalu River Region," International Journal of Korean History 25, no. 2 (August 2020): 110-115. 
France. Mostly invisible to the naked eye, they occasionally surface on the maps: in a discreet tribute to Ptolemy, Yi Hoe and Fine both significantly downsize India, and Fine indicates Montes Lunae which also appears on the Honkōji Kangnido under the entry 這不魯哈麻 (zhebuluhama). Besides, the tools Fine used for calculating coordinates were remotely derived from Chinese or Arab inventions, which, improved by Koreans, contributed to Chosŏn's state-of-the-art geographical surveys in the $15^{\text {th }}$ century and to the exactitude of relative distances within China and the Korean peninsula on the Ryūkoku Kangnido. This is not to allege that early modern relations between France and Korea were channeled through direct court or individual exchanges. Instead, the technological foundations of Yi Hoe and Fine's maps better fit within a Eurasian history of techniques which allows for the cross-breeding of technical generations along discordant times and scales. ${ }^{116}$

Admittedly, most maps are a compromise between science and ignorance. This study argued that the delusions of landscape painting and perspective were crucial in hiding the cartographers' dubiety or blowing their advanced state of knowledge. Here, a second category of voids focused on the visual effects -as opposed to theoretical precepts- resulting from these painting techniques. On the examined maps, one cannot help but notice unreasonable disproportions between different pictorial elements. Thanks to trapezoidal and heart-shaped projections Fine makes optimal use of vanishing lines to underrepresent the areas of the globe he ignores. With all the caution that this analogy requires, Yi Hoe and later the Ryūkoku Kangnido cartographer resort to inequal scales, which landscape painting thrives on, to enlarge China and Korea to the detriment of Japan, India, Central Asia, Africa and Europe, not to mention the areas that conveniently disappear off the frame. On the Ryūkoku Kangnido, voids are created along the Northern frontier and other neuralgic areas like counties,

116 Guillaume Carnino, Liliane Hilaire-Pérez and Aleksandra Kobiljski, Histoire des techniques, Mondes, sociétés, cultures (XVI ${ }^{e}$-XVIII ${ }^{e}$ siècle) (Paris: PUF, 2016), 21, 485. 
navy and military bases. Where Yi Hoe deflates bordering areas, Fine inflates them. In doing so, both scoop them out of toponyms and resort to imaginary oronymic and fluvial representations. These painting techniques were not exclusive to these cartographers. Neither was the fact that these maps happened to be politicized by their burgeoning political regimes -the Yi and Valois dynasties. But this study stressed that on these maps, and potentially on others, the correlations between these techniques, their conceptual apparatus and their cartographic instrumentalization have been under-researched.

If one accepts the premises that the art of not showing everything is conducive to transformations ${ }^{117}$ and the balance between Alberti's varietas and vacuum brings forward new values, ${ }^{118}$ as landscape painting and perspective respectively do, then these painting traditions were not simply ornamental or accidentally compatible with the (in)visualization of scientific as well as political messages. The broader signification of spatial discontinuities and decentering - the third category of voids- can also be found in the conceptual, not just technical, underpinnings of these painting traditions. Robinson recognizes that only Chosŏn Korea is gratified with place-names updates between the 1402 and the Ryūkoku Kangnido. ${ }^{119}$ As Short formulated it, "a contemporaneous Korea is embedded in an anachronistic world." 120 This was certainly not alien to the broader rectification of names that the Neo-Confucians were implementing either in the form of the general Confucianisation of toponyms, ${ }^{121}$ the creation of a vernacular script han'gŭl (1446) or the promulgation of the Kyŏngguktaejŏn (經國大典, National Code, 1471), which all took place between the two examined versions of the Kangnido. On some landscape

117 Cheng, Vide, 45.

118 Arasse, Le Détail, 149-155.

119 Robinson, "Chosŏn Korea," 183-186.

120 Short, Korea, 5-6.

121 Kim Sunbae, "The Confucian Transformation of Toponyms and the Coexistence of Contested Toponyms in Korea," Korea Journal 52, no. 1 (Spring 2012): 105139. 
paintings, textual addenda were also used to create spatial depth. ${ }^{122}$ On others, a double perspective simultaneously offered an aerial view and an oblique projection. Such a decentered perspective surreptitiously incited the viewers to gaze at something unspoken and apparently invisible which actually turned out to be the true theme of the painting. ${ }^{123}$ A decentred reading of the Ryūkoku Kangnido would indeed feed the alternative narrative according to which, through an enlarged, toponymically updated peninsula, Chosŏn leaders were claiming for themselves more than the vassal status the tributary system granted them. In Europe, Ghiberti and Uccello had invented their own versions of bifocal perspectives. But Fine's maps are unequivocally centred on France. The most dissident, and decentered, elements therefore lie in the fact that Fine seeks to turn political defeats into cartographic victories. In 1519, Francis I lost the elections to the throne of the Holy Roman Empire to Charles V. At the bottom of France map, Charles V's terrestrial and spiritual empires are cornered into insignificant Espaigne and Romme. Like Mt. Kunlun on the Ryūkoku Kangnido, the Holy See is omitted; and like Mt. Paektu on the Ryūkoku Kangnido, Mt. Sinai appears with no specific mention on Fine's world map, whereas Jerusalem was still on top of contemporaneous Eastoriented mappae mundi. Far from being trivial, this shift from spiritual canons directly derives from the main characteristic of perspectiva artificialis, which became "open to the interests of man." 124 "At [his] own risks," 125 Fine was thus designing a map to be seen from the perspective of Francis I, not God.

Under a fourth a category of temporal voids, extrapolating painting concepts to cartography yields unexpected results. Alberti conceived his panels as theatrical scenes where the storia unfolds. That is to say, the unification of place did not necessarily suppose a temporal unification

122 Cheng, Vide, 25.

123 Cheng, Vide, 23.

124 Arasse, Histoires, 66.

125 Fine, "Légende," 93. 
and the story could be represented along "three different temporalities". ${ }^{126}$ Extending the connection between perspective, cartography and history, it is interesting to note that many maps in $16^{\text {th }}$ century France and beyond were entitled theatrum, implying some kind of illustrated narration. Diachronicity is patent on the 1525 France map where a past Gaul and a contemporaneous France are superposed. This historical depth is furthered by four later versions in 1538, 1546, 1553 and 1557 which were deemed sufficiently realistic to be continuously reedited without modifications up to three decades later. This would seem to indicate that Fine's maps could have been designed from a three-fold temporality which not only echoed past glories in the present but also projected future conquests in the $16^{\text {th }}$ century and even beyond. To give substance to this claim, one only has to acknowledge the fact that the cartographic imprecisions on Fine's maps, whose different editions punctuate the Italian Wars, are but reflections of geopolitical fluctuations on the Eastern border. The first edition of France map (1525) coincided with the defeat of Pavia and the loss of the province of Milan while the second one is published in 1538, two years only after Francis I reconquered Bresse, Bugey, Savoie and the Northern Piedmont (January-February 1536). Further up North, the mutacions (i.e.: the word then used for "changes") of the Eastern border are still an issue at the end of Fine's life: in 1552, five years before the last publication of his France map (1557), the city of Metz and the bishoprics of Toul and Verdun are occupied by Henri II -Francis I's successor- while Lyon remains a "quasi-border city." 27 With the assistance of perspective, Fine's maps can therefore be seen as concave mirrors in which past, present and future events converge towards the optical and conceptual axis of their viewers.

This floating temporality also characterizes the Kangnido: eight decades separate its first version (1402) from the Ryūkoku one (1479-1485), and one more century the latter from the Honkōji, Tenri and Honmyōji

126 Arasse, Histoires, 66-70.

127 Arlette Jouanna, La France du XVI siècle, 1483-1598 (Paris: PUF, 2016), 4. 
versions (circa 1560). On all four versions of the Kangnido, on the earlier cartographic models they drew inspiration from and on later Korean maps, the Northern area was compressed and distorted by cartographers until the $18^{\text {th }}$ century. As far as the sole $15^{\text {th }}$ century is concerned, Jing Liu and Yan Piao convincingly stressed that the geopolitical "vagueness of the Korea-China frontier" "128 was due to unstable Chosŏn-Ming relations. Yet the fact that the same vagueness and voids were cartographically translated and perpetuated before and beyond the time frame comprised within the 1402 and Ryūkoku Kangnido suggests that maps were not mere repositories of time-bound realities. As with landscape paintings, the ritual of unfolding and contemplating maps meant renewing past temporalities as well as predicting future ones.

\section{References}

1. Ahn, Hwijoon. "Early Cartography and Painting." In The Artistry of Early Korean Cartography, edited by Han Youngwoo, Ahn Hwijoon, Bae Woosung, 133-183. Honolulu: University of Hawai'i Press, 2009.

2. Alberti, Leon-Battista. De la peinture. Translated by Claudius Popelin. Paris: A. Lévy, 1868.

3. Arasse, Daniel. Le Détail. Paris: Flammarion, 1996.

4. Arasse, Daniel. Histoires, Histoires de peinture. Paris: Gallimard, 2004.

5. Axworthy, Angela. Le mathématicien renaissant et son savoir, Le statut des mathématiques selon Oronce Fine. Paris: Classiques Garnier, 2016.

6. Bae, Kichan. Le roi Sejong le Grand. Séoul: Diamond Sutra group, 2001.

7. Bae, Woosung. "Joseon Maps and East Asia, Mapping the World: the Joseon Worldview as seen through old maps." In The Artistry of Early Korean Cartography, edited by Han Youngwoo et al., 93-132. Honolulu: University of Hawai'i Press, 2009.

128 Liu and Piao, "Expansion,” 110-115. 
8. Brioist, Jean-Jacques. "Oronce Fine and cartographical methods." In The Worlds of Oronce Fine, edited by Alexander Marr, 137-155. Donington: Shaun Tyas, 2009.

9. Broc, Numa. "Quelle est la plus ancienne carte 'moderne' de la France ?.” Annales de Géographie 92, no. 513, (1983): 513-530.

10. Brotton, Jerry. A History of the World in 12 Maps. New York: Viking, 2013.

11. Busan Historical and Cultural Collections. "Reproduction of the Ryūkoku Kangnido.” Accessed December 15, 2020. http://busan.gr andculture.net/Contents/Index?local=busan.

12. Carnino, Guillaume, Hilaire-Pérez, Liliane, and Kobiljski, Aleksandra. Histoire des techniques, Mondes, sociétés, cultures (XVI ${ }^{e}$-XVIII ${ }^{e}$ siècle). Paris: PUF, 2016.

13. Cattaneo, Angelo. "World Cartography in the Jesuit Mission in China. Cosmography, Theology, Pedagogy." In Education for New Times: Revisiting Pedagogical Models in the Jesuit Tradition, edited by Artur K. Wardega S.J., 71-86. Macau: Macau Ricci Institute, 2014.

14. Cha, Hyewon. "Was Joseon a Model or an Exception? Reconsidering the Tributary Relations during Ming China." Korea Journal 51, no. 4 (Winter 2011): 33-58.

15. Chastel, André. "L'artiste." In L'homme de la Renaissance, edited by Eugenio Garin, 255-288. Paris: Seuil, 2002.

16. Che, Honggyu. "Map commentaries." In Old Maps of Korea, Han'guk ko chido, edited by Yi Chan, 221-230. Seoul: Han'guk Tosogwanhak Yon'guhoe, 1977.

17. Cheng, François. Vide et plein, Le langage pictural chinois. Paris: Seuil, 1991.

18. Cheng, François. Souffle-Esprit. Textes théoriques chinois sur l'art pictural. Paris: Seuil, 2006.

19. Choi, Changmo. "Chosŏnshidae kojidoŭi arabia • ap'ŭrik'a ihae sogo," Han'gukkojidoyŏn'guhak'oe haksultaehoe (2012): 23-52.

20. Clouet, Jean. "Antoine Macault lisant sa traduction au roi François I ${ }^{\mathrm{er}}$ et à sa cour, Les trois premiers livres de Diodore de Sicile." RMN 
Grand Palais, Domaine de Chantilly, Musée Condé. Accessed December 15, 2020. https://www.photo.rmn.fr/archive/01-0049202C6NU0GQF8JP.html.

21. Dainville, François de. "Cartographie historique occidentale." Annuaire 1969-1970, École pratique des hautes études. 4e section, Sciences historiques et philologiques (1970): 523-534.

22. Dubois, Jean, Mitterrand, Henri, and Dauzat, Albert. Dictionnaire étymologique. Paris: Larousse, 2007.

23. Dupré, Sven. "Printing practical mathematics." In The Worlds of Oronce Fine, edited by Alexander Marr, 64-82. Donington: Shaun Tyas, 2009.

24. Eyssette, Jérémie. Le Déroulement des Mondes, l'instrumentalisation cartographique du néoconfucianisme en Corée et de la Renaissance en France ( $X V^{e}-X V I^{e}$ siècles). Paris: L'Harmattan, 2020.

25. Feng, Linda Rui. "Can Lost Maps Speak? Toward a Cultural History of Map Reading in Medieval China." Imago Mundi 70, Part 2 (2018): 169-182.

26. Fine, Oronce. "Recens et integra orbis descriptio." Bibliothèque nationale de France. Accessed December 15, 2020, http://expositio ns.bnf.fr/lamer/grand/054.htm.

27. Fine, Oronce. "Nova totius Galliae description." Universität Basel. Accessed December 15, 2020. https://www.e-rara.ch/bau_1/content/ zoom/3946213.

28. Fine, Oronce. "Légende de la Recens et integra orbis descriptio." Quoted in Lt-colonel Langlois, "Étude sur deux cartes d'Oronce Fine de 1531 et 1536." Journal de la Société des Américanistes 14-15 (1922): 83-97.

29. Fumaroli, Marc. Les origines du Collège de France (1500-1600). Paris: Collège de France, 1998.

30. Gaffiot, Félix. Dictionnaire Latin-Français. Paris: Hachette, 1990.

31. Gallois, Lucien. "Un géographe dauphinois: Oronce Fine et le Dauphiné sur sa carte de France de 1525." Recueil des travaux de l'Institut de géographie alpine 6, no. 1 (1918): 1-25. 
32. Gallois, Lucien. "La grande carte de France d'Oronce Fine," Annales de Géographie 44, no. 250 (1935): 337-348

33. Gallois, Lucien. "Oronce Fine et sa grande carte de France de 1525," Bulletin de l'Association de géographes français $99,13^{\mathrm{e}}$ année (juillet-octobre 1936): 107-115.

34. Garnier, Edith. Guillaume du Bellay, l'ange gardien de François I ${ }^{e r}$. Paris: Félin, 2016.

35. Han, Youngwoo. "The historical development of Korean cartography." In The Artistry of Early Korean Cartography, edited by Han Youngwoo et al., 3-92. Honolulu: University of Hawai'i Press, 2009.

36. Institute of Korean Studies "Colored reproduction of the Ryūkoku Kangnido." Kyujanggak. Accessed December 15, 2020. http://kyud b.snu.ac.kr/book/view.do.

37. Jouanna, Arlette. La France du XVI siècle, 1483-1598. Paris: PUF, 2016.

38. Kawamura, Hirotada. “川 村博忠，近世絵図の地図性 一 地図の向 き一”地理科学 45.3 (1990): 137-143.

39. Kenzheakhmet, Nurlan. "The place names of Central Asia in the Kangnido." Journal of Asian History 49 (2015): 141-160.

40. Kenzheakhmet, Nurlan. "The Place Names of Euro-Africa in the Kangnido." The Silk Road 14 (2016): 106-125.

41. Kim, Seonmin. "Hunchun, the Qing-Chosŏn Borderland in the Eighteenth Century." International Journal of Korean History 21, no. 1 (February 2016): 157-191.

42. Kim, Sunbae. "The Confucian Transformation of Toponyms and the Coexistence of Contested Toponyms in Korea." Korea Journal 52, no. 1 (Spring 2012): 105-139.

43. Kwŏn Kŭn "Commemoration of the Kangnido." Quoted in Gari Ledyard, "Cartography in Korea." In The History of Cartography, edited by Catherine Delano Smith, Nathan Sivin, Cordell Yee, et al., 235345. Chicago: J.B. Harley et D. Woodward, 1994.

44. Langlois, Lt-colonel, "Étude sur deux cartes d'Oronce Fine de 1531 et 1536." Journal de la Société des Américanistes 14-15 (1922): 83-97. 
45. Ledyard, Gari. "Cartography in Korea." In The History of Cartography, edited by Catherine Delano Smith, Nathan Sivin, Cordell Yee, et al., 235-345. Chicago: J.B. Harley et D. Woodward, 1994.

46. Lee, Jungshin. 'Koreans' Perceptions of the Liaodong Region During the Chosŏn Dynasty." International Journal of Korean History 21, no. 1 (February 2016): 47-85.

47. Liu, Jing, and Piao, Yan. "Expansion, Contestation, and Boundary Making: Chosŏn Korea and Ming China's Border Relations over the Yalu River Region.” International Journal of Korean History 25, no. 1 (February 2020): 105-142.

48. Marr, Alexander. The worlds of Oronce Fine, Mathematics, Instruments and Print in Renaissance France. Donington: Shaun Tyas, 2009.

49. Nadiras, Sébastien. "1308. A l'égal du pape et de l'empereur: le roi de France à Lyon." In Histoire mondiale de la France, edited by Patrick Boucheron, 194-198. Paris: Seuil, 2017.

50. Oh, Kilsun. “Wŏn'gyŏngsedaejŏnjirido e naonŭn chimyŏng ŭi chosa wa Honil kangni yŏktae kukto chi to sŏyŏkchimyŏng gwaŭi pigyo." Han'gukkojidoyŏn'gu 2, no. 2 (2010): 83-105.

51. Oh, Sanghak. "Chosŏnshidaeŭi ilbonjido wa ilbon inshik." Taehanjirihak'oeji 38, no. 1 (2003): 32-47.

52. Oh, Sanghak. "Chosŏnshidae segyejido wa chunghwajŏk segyeinshik." Han'gukkojidoyŏn'gu 1, no.1 (2009): 5-18.

53. Oh, Sanghak. "Honil kangni yŏktae kukto chi to tamnon ŭi pip'anjŏk kŏmt'o.” Han'gukkojidoyŏn'guhak'oe haksultaehoe (2012): 91-109.

54. Oh, Sanghak. "Honil kangni yǒktae kukto chi to ŭi ch'oegŭn tamnon gwa chido ŭi chaep'yŏngga.” Kukt'ojirihak'oeji 50, no. 1 (2016): 117-134.

55. Okada, Yoshihiro. "Ch'ogojŏngmil hwasangch'ŏri e ŭihan Honil kangni yŏktae kukto chi to ŭi kwahakpunsŏk." Han'gukkojido yŏn'guhak'oe haksultaehoe (2012): 85-88.

56. Pantin, Isabelle. "Oronce Fine's Role as Royal Lecturer." In The Worlds of Oronce Fine, edited by Alexander Marr, 13-30. Donington: Shaun Tyas, 2009.

57. Pelletier, Monique. Cartographie de la France et du monde de la 
Renaissance au Siècle des lumières. Paris: Éditions de la Bibliothèque nationale de France, 2002.

58. Pelletier, Monique. De Ptolémée à La Guillotière ( $X V^{e}-X V I^{e}$ siècles). Des cartes pour la France, pourquoi, comment?. Paris: CTHS, 2009.

59. Pelletier, Philippe. L'Extrême-Orient. L'invention d'une histoire et d'une géographie. Paris: Gallimard, 2011.

60. Robinson, Kenneth. "Chosŏn Korea in the Ryūkoku Kangnido: Dating the Oldest Extant Korean Map of the World (15 ${ }^{\text {th }}$ century)." Imago Mundi 59, Part 2 (2007): 177-192.

61. Robinson, Kenneth. "Yi Hoe and His Korean Ancestors in T'aean Yi Genealogies." Seoul Journal of Korean Studies 21, no. 2 (December 2008): 221-250.

62. Robinson, Kenneth. "Gavin Menzies, 1421, and the Ryūkoku Kangnido.” Ming Studies 61 (April 2010): 56-70.

63. Robinson, Kenneth. "Daoist Geographies in Three Korean World Maps." Journal of Daoist Studies 3 (2010): 91-116.

64. Schipper, Christofer. "Le chinois." In Tour du monde des concepts, edited by Pierre Legendre, 135-188. Paris: Fayard, 2013.

65. Short, John. Korea, A Cartographic History. Chicago: University of Chicago Press, 2012.

66. Singaravélou, Pierre and Argounès, Fabrice. Le monde vu d'Asie, Une histoire cartographique. Paris: Seuil, 2018.

67. Tiberghien, Gilles. Finis Terrae. Imaginaires et imaginations cartographiques. Paris: Bayard, 2007.

68. Wieger, Léon. Chinese characters, Their origin, etymology, history, classification and signification. New York: Dover Publications, 1965. 


\section{Painting the Void: The Instrumentalization of Cartography in Neo-Confucian Chosŏn and Renaissance France through Landscape Painting and Perspective $\left(15^{\text {th }}-16^{\text {th }}\right.$ centuries $)$}

At prima facie, the Ryūkoku Kangnido (1479-1485) is a tribute to sinocentrism in its scientific, cultural and political expressions. But the examination of data surfacing on the map and its commemoration is often conducted to the detriment of the interplay between what is shown and what is intentionally shunted off the map. Repairing this imbalance by investigating the nature of cartographic "voids" is instructive in at least three ways. Subjacent epistemic and technological connections can be established between the Ryūkoku Kangnido and Western cartography -here, Oronce Fine's Recens et integra orbis descriptio (1536) and Nova totius Galliae descriptio (1538). More fundamentally, this study contends that the Ryūkoku Kangnido and Fine's maps are structured by techniques and concepts borrowed from landscape painting and perspective. Compatible with the scientific and political polarities between knowledge and ignorance, secrecy and ostentation, this approach can also yield new insights into the cartographic instrumentalization of Neo-Confucian Chosŏn and Renaissance France.

Keywords: Ryūkoku Kangnido (1479-1485); Recens et integra orbis descriptio (1536); Nova totius Galliae descriptio (1538); NeoConfucian Chosŏn; Renaissance France; cartographic instrumentalization; landscape painting; perspective. 


\section{〈국문초록〉}

\section{여백(餘白) 표현: 조선 성리학과 프랑스 르네상스 시대 (15-16세기)에 산수화와 원근법을 통해 제작된 지도 도구화}

Jérémie Eyssette (조선대학교)

류코쿠 강리도 (혼일강리역대국도지도 混一疆理歷代國都之圖, 1479-1485)는 일견 중국 중심주의에 대한 과학적, 문화적, 정치적 헌사처럼 보인다. 그러나 지도와 그것의 서문에서 나타난 정보를 분석해 보면, 보여지는 것과 의도적으로 숨겨진 것 사이의 상 호작용을 감안하지 않은 채 분석이 추진되어 왔다. 지도제작에서 이와 같은 《여백(餘 白)»의 본질을 검토하여 불균형을 바로잡는 것은 세 가지 사고 기조를 열어 준다. 류 코쿠 강리도와 서양지도 제작 간에 기술 및 인식론적으로 연관될 수 있다 - 서양 지도 로는 대표적으로 오롱스 핀의 Recens et integra orbis descriptio (세계지도, 1536)와 Nova totius Galliae descriptio (프랑스 지도, 1538)가 있다. 본 연구는 더 근본적으로 류 코쿠 강리도와 핀의 지도가 산수화와 원근법의 기법 및 개념으로 구성되어 있다고 주 장한다. 이와 같은 접근법은 지식과 무지, 비밀과 과시 사이의 과학적, 정치적 양극성 과 양립할 수 있으며, 또한 조선의 성리학과 프랑스의 르네상스 지도 도구화에 새로운 관점을 제공할 수 있다.

주제어: 류코쿠 강리도(혼일강리역대국도지도, 1479-1485) ; Recens et integra orbis descriptio (오롱스 핀의 세계지도, 1536) ; Nova totius Galliae descriptio (오롱스 핀의 프랑스 지도, 1538) ; 조선 성리학; 프랑스 르네상스; 지도 도구화 ; 산수화; 원근법. 